Retraction

\title{
Retracted: Green Synthesis of Silver Nanoparticles Using Polyalthia longifolia Leaf Extract along with D-Sorbitol: Study of Antibacterial Activity
}

\author{
Journal of Nanotechnology \\ Received 17 September 2018; Accepted 17 September 2018; Published 7 March 2019 \\ Copyright (C) 2019 Journal of Nanotechnology. This is an open access article distributed under the Creative Commons Attribution \\ License, which permits unrestricted use, distribution, and reproduction in any medium, provided the original work is \\ properly cited.
}

Journal of Nanotechnology has retracted the article titled "Green Synthesis of Silver Nanoparticles Using Polyalthia longifolia Leaf Extract along with D-Sorbitol: Study of Antibacterial Activity" [1]. As raised on PubPeer, the article was found to contain images with signs of duplication and manipulation in Figures 3 and 4 . The background of Figure 3 shows repeating features. In Figure 4, (b) in the top row is identical to (a) in the bottom row. Additionally, (b) and (c) in the bottom row of Figure 4 are identical to (c) and (b) in Figure 7 in another article by the same group of authors [2].

\section{References}

[1] S. Kaviya, J. Santhanalakshmi, and B. Viswanathan, "Green synthesis of silver nanoparticles using Polyalthia longifolia leaf extract along with D-sorbitol: study of antibacterial activity," Journal of Nanotechnology, vol. 2011, Article ID 152970, 5 pages, 2011.

[2] S. Kaviya, J. Santhanalakshmi, B. Viswanathan, J. Muthumary, and K. Srinivasan, "Biosynthesis of silver nanoparticles using Citrus sinensis peel extract and its antibacterial activity," Spectrochimica Acta Part A: Molecular and Biomolecular Spectroscopy, vol. 79, no. 3, pp. 594-598, 2011, ISSN 1386-1425. 


\title{
Green Synthesis of Silver Nanoparticles Using Polyalthia longifolia Leaf Extract along with D-Sorbitol: Study of Antibacterial Activity
}

\author{
S. Kaviya, ${ }^{1}$ J. Santhanalakshmi, ${ }^{1}$ and B. Viswanathan ${ }^{2}$ \\ ${ }^{1}$ Department of Physical Chemistry, University of Madras, Chennai 600 025, India \\ ${ }^{2}$ National Center for Catalysis Research, Indian Institute of Technology, Chennai 600 036, India
}

Correspondence should be addressed to S. Kaviya, kaviyahere@gmail.com

Received 23 March 2011; Accepted 16 June 2011

Academic Editor: Mallikarjuna Nadagouda

Copyright () 2011 S. Kaviya et al. This is an open access article distributed under the Creative Commons Attribution License, which permits unrestricted use, distribution, and reproduction in any medium, provided the original work is properly cited.

Synthesis of silver nanoparticles (AgNPs) using Polyalthia longifolia leaf extract as reducing and capping agent along with Dsorbitol used to increase the stability of the nanoparticles has been reported. The reaction is carried out at two different concentrations $\left(10^{-3} \mathrm{M}\right.$ and $\left.10^{-4} \mathrm{M}\right)$ of silver nitrate, and the effect of temperature on the synthesis of AgNPs is investigated by stirring at room temperature $\left(25^{\circ} \mathrm{C}\right)$ and at $60^{\circ} \mathrm{C}$. The UV-visible spectra of NPs showed a blue shift with increasing temperature at both concentrations. FT-IR analysis shows that the biomoites played an important role in the reduction of $\mathrm{Ag}^{+}$ions and the growth of AgNPs. TEM results were utilized for the determination of the size and morphology of nanoparticles. The synthesized silver nanoparticles are found to be highly toxic against Gram-positive bacteria than Gram-negative bacteria.

\section{Introduction}

An important area of research in nanotechnology is the synthesis of nano silver particles. Silver has long been recognized as having an inhibitory effect towards many bacterial strains and microorganisms [1]. Antibacterial activity of the silvercontaining materials used in medicine to reduce infections in burn treatment [2] and arthroplasty [3], as well as to prevent bacteria colonization on prostheses [4], catheters [5], vascular grafts, dental materials [6], stainless steel materials [7], and human skin [8]. Silver nanoparticles also exhibit a potent cytoprotective activity towards HIV-infected cells [9]. Because of such wide range of applications, numerous synthetic methods have been developed [10]. Biological routs of nanoparticles synthesis using microorganism [11-13], enzyme [14] and plant or plant extract [15-21] have been suggested as possible ecofriendly alternatives to chemical and physical methods. Using plant for nanoparticles synthesis can be advantageous over other biological processes by eliminating the elaborate process of maintaining cell cultures [22]. It can also be suitably scaled up for large-scale synthesis of nanoparticles. Specific surface area is relevant for catalytic reactivity and other related properties such as antimicrobial activity in silver nanoparticles.

Polyalthia longifolia is a lofty evergreen tree, native to India, commonly planted due to its effectiveness in alleviating noise pollution. Methanolic extract of Polyalthia longifolia have yielded 20 known and 2 new organic compounds, some of which show cytotoxic properties [23]. Here in, we report for the first time synthesis of silver nanoparticles using aqueous extract derived from Polyalthia longifolia leafs with D-sorbitol and their catalytic and antibacterial activity of the synthesized NPs is described.

\section{Experimental}

The Polyalthia longifolia leaves were collected from University of Madras Campus located at Chennai, India. All the chemicals were obtained from Aldrich and experiments done in triplicates. Double-distilled water was used for the experiments. Fresh leaves of Polyalthia longifolia were collected, washed thoroughly with double-distilled water, and incised into small pieces. About $4 \mathrm{~g}$ of finely cut Polyalthia longifolia leaves were weighed and transferred into 
a $250 \mathrm{~mL}$ beaker containing $40 \mathrm{~mL}$ double-distilled water, mixed well, and boiled for $2 \mathrm{~min}$. The extract obtained was filtered through Whatman number 1 filter paper, and the filtrate was collected in $250 \mathrm{~mL}$ Erlenmeyer flask and stored at $4^{\circ} \mathrm{C}$ for further use.

Aqueous solution of $10^{-3} \mathrm{M}$ and $10^{-4} \mathrm{M}$ silver nitrate $\left(\mathrm{AgNO}_{3}\right)$ and $10^{-2} \mathrm{M}$ of $\mathrm{D}$-sorbitol was prepared and used for the synthesis of silver nanoparticles. $3 \mathrm{~mL}$ of extract and $1 \mathrm{~mL}$ of D-sorbitol were added to $40 \mathrm{~mL}$ of $\mathrm{AgNO}_{3}$ solution. The effect of temperature on the synthesis of silver nanoparticles was carried out at room temperature $\left(25^{\circ} \mathrm{C}\right)$ and $60^{\circ} \mathrm{C}$. The silver nanoparticles synthesized using Polyalthia longifolia leaf extract was tested for antimicrobial activity by agar well diffusion method against pathogenic bacteria Escherichia coli, Pseudomonas aeruginosa (Gram negative), and Staphylococcus aureus (Gram positive). The pure cultures of bacteria were subcultured on nutrient agar medium. Each strain was swabbed uniformly onto the individual plates using sterile cotton swabs. Wells of $10 \mathrm{~mm}$ diameter were made on nutrient agar plates using gel puncture. Using a micropipette, $50 \mu \mathrm{L}$ of nanoparticle solution was poured onto each well on all plates. After incubation at $37^{\circ} \mathrm{C}$ for 24 hours, the different levels of zone of inhibition of bacteria were measured.

The bioreduction of $\mathrm{Ag}^{+}$ion in solution was monitored using UV-visible spectrometer (Techomp 8500 spectrometer). Further characterization was done using FTIR (Bruker tensor 27) spectrometer. The extract was centrifuged at $5000 \mathrm{rpm}$ for $30 \mathrm{~min}$ and the resulting suspension was redispersed in $10 \mathrm{~mL}$ sterile distilled water. The centrifuging and redispersing process was repeated three times. Finally, the dried form of extract was palletized with $\mathrm{KBr}$ and analyzed using FTIR. The morphology of the AgNPs was examined using transmission electron microscopy (JEOL 3010 TEM). The films of the samples were prepared on a carbon coated copper grid by dropping a small amount of the sample and then allowing it to dry.

\section{Results and Discussion}

The time of addition of extract into the metal ion solution was considered as the start of the reaction. It is well known that silver nanoparticles exhibit yellowish brown color in aqueous solution due to excitation of surface plasmon vibrations in silver nanoparticles [15]. As the Polyalthia longifolia leaf extract was mixed in the aqueous solution of the silver ion complex and D-sorbitol, initially the color changed from watery to yellowish brown due to the reduction of silver ion. The reduction rate is found to increase with the reaction temperature [24]. For $10^{-3} \mathrm{M}$ solution the addition of $3 \mathrm{~mL}$ of extract to the reaction mixture, the reaction completed by $1.30 \mathrm{~h}, 1 \mathrm{~h}$ while $10^{-4} \mathrm{M}$ solution the reaction completed by $1 \mathrm{~h}, 40 \mathrm{~min}$ at $25^{\circ} \mathrm{C}$ and $60^{\circ} \mathrm{C}$, respectively.

$\mathrm{UV}$-vis spectroscopy could be used to examine size and shape controlled nanoparticles in aqueous suspensions [25]. Figure 1 shows the UV-vis spectra which are recorded after the completion of the reaction. For $10^{-3} \mathrm{M}$ solution, the silver nanoparticles have absorbance peak at $451 \mathrm{~nm}$ and $435 \mathrm{~nm}$, and $10^{-4} \mathrm{M}$ solution has peak at $425 \mathrm{~nm}$ and $422 \mathrm{~nm}$

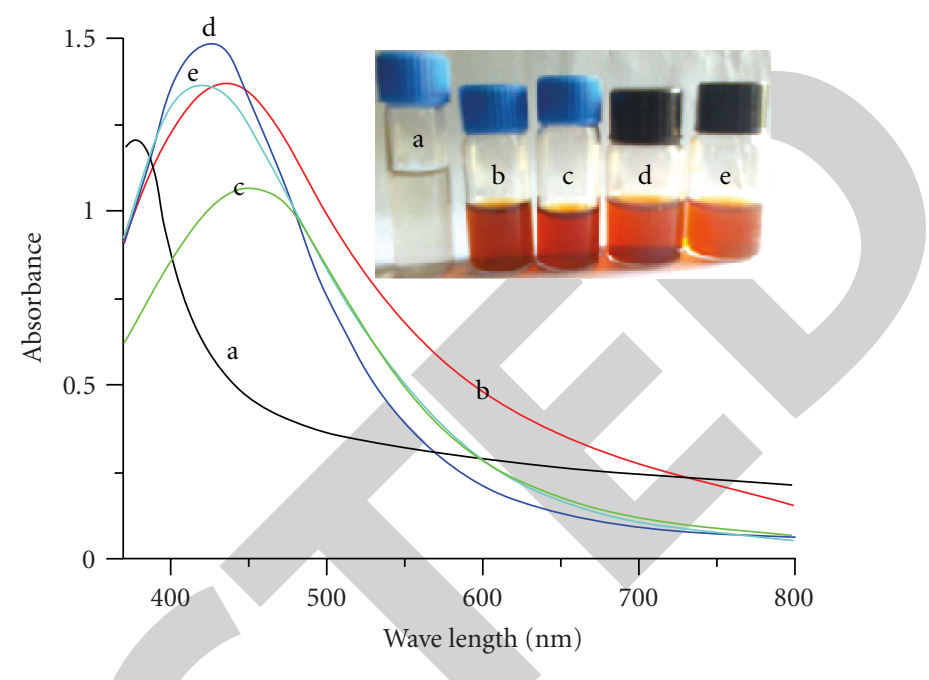

FIgure 1: UV-vis absorption spectrum of (a) Polyalthia longifolia leaf extract, biosynthesized silver nanoparticles of different concentration $\left(10^{-3} \mathrm{M}\right.$ and $\left.10^{-4} \mathrm{M}\right)$ at (b and d) $25^{\circ} \mathrm{C}$, (c and e) $60^{\circ} \mathrm{C}$.

for reaction at $25^{\circ} \mathrm{C}$ and $60^{\circ} \mathrm{C}$, respectively. The frequency and width of the surface plasmon absorption depend on the size and shape of the metal nanoparticles as well as on the dielectric constant of the metal itself and the surrounding medium [24]. Supposing the same particle shape, medium dielectric constant and temperature, the mean diameter of the nanoparticles strongly influence the SPR band in aqueous solution [25]. The spectrum shows the blue shift with raising temperature. This blue shift indicates the reduction of mean diameter of the biogenic silver nanoparticles [24, 26, 27].

FT-IR measurements were carried out to identify the possible biomolecules responsible for the reduction of the $\mathrm{Ag}^{+}$ions and capping of the bioreduced silver nanoparticles synthesized by Polyalthia longifolia leaf extract along with D-sorbitol. Figure 2(b) represents the FTIR spectrum of Dsorbitol and shows bands at $2938 \mathrm{~cm}^{-1}$ (C-H stretching in alkanes) and $1645 \mathrm{~cm}^{-1}(\mathrm{C}=\mathrm{O}$ stretch of carbonyls). Figure 2(a) represents the FTIR spectrum of the leaf extract and shows peaks at 1637, 1418, and $1063 \mathrm{~cm}^{-1}$. These peaks are known to be associated with the amide I arise due to carbonyl stretch in proteins $\left(1637 \mathrm{~cm}^{-1}\right),-\mathrm{C}-\mathrm{C}-$ stretch (in ring) aromatic $\left(1418 \mathrm{~cm}^{-1}\right)$ [28], and $\mathrm{C}-\mathrm{N}$ stretching vibration of amine $\left(1063 \mathrm{~cm}^{-1}\right)$ [29], respectively. Proteins present in the extract can bind to AgNP through either free amino or carboxyl groups in the proteins [30]. Experimentally, D-sorbitol does not have the potential to reduce the silver ions in the solution, but it may cap the formed silver nanoparticles through electrostatic attraction or bind to the protein groups in the extract via hydrogen bond and increase the stability of the silver nanoparticles. It indicates that the functional groups in biomolecules are mainly responsible for the reduction of silver ions.

The silver nanoparticles are spherical in shape and are not aggregated in solution with raising temperature (Figure 3). This is due to the binding force between the AgNPs and the capping molecules that may get decreased with increasing temperature even though the size of the 


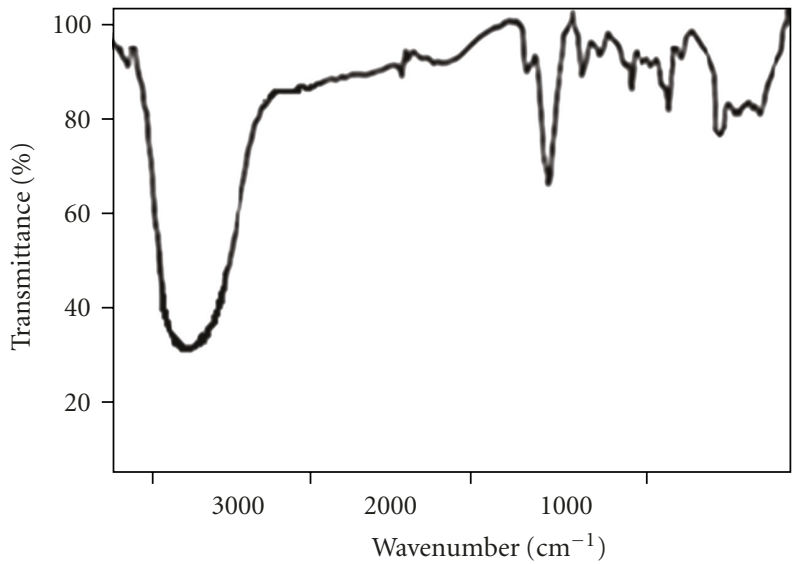

(a)

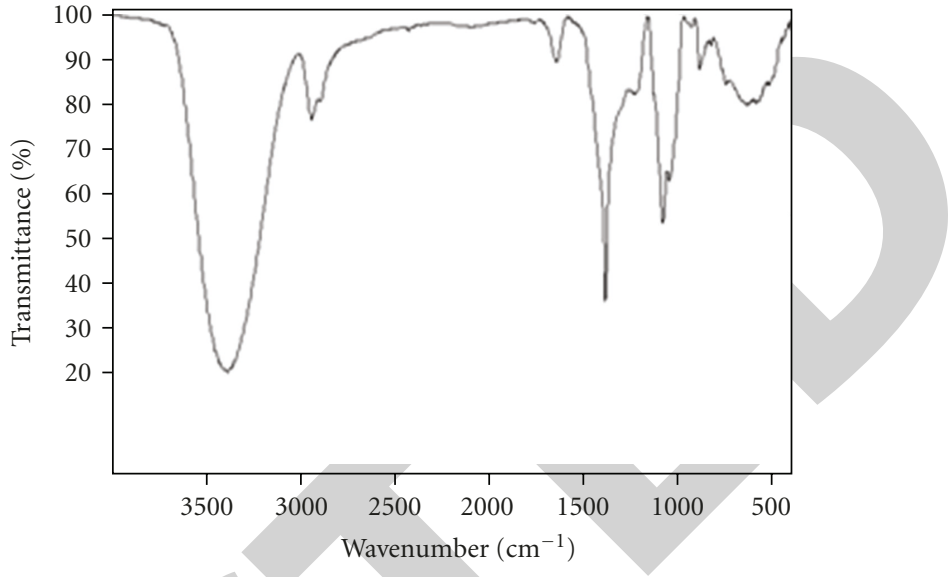

(b)

FIGURe 2: FTIR spectrum of (a) Polyalthia longifolia leaf extract and (b) D-sorbitol.

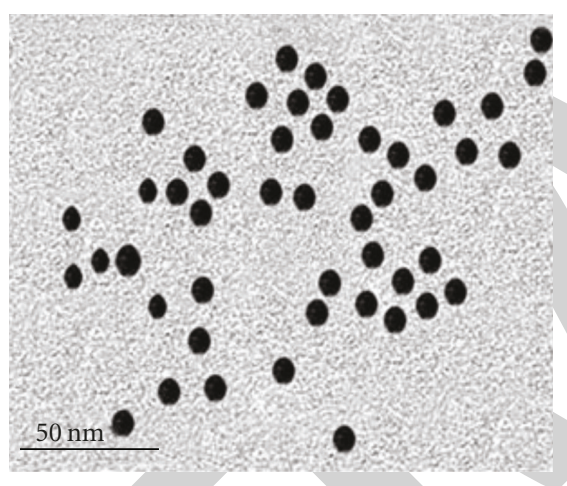

(a)

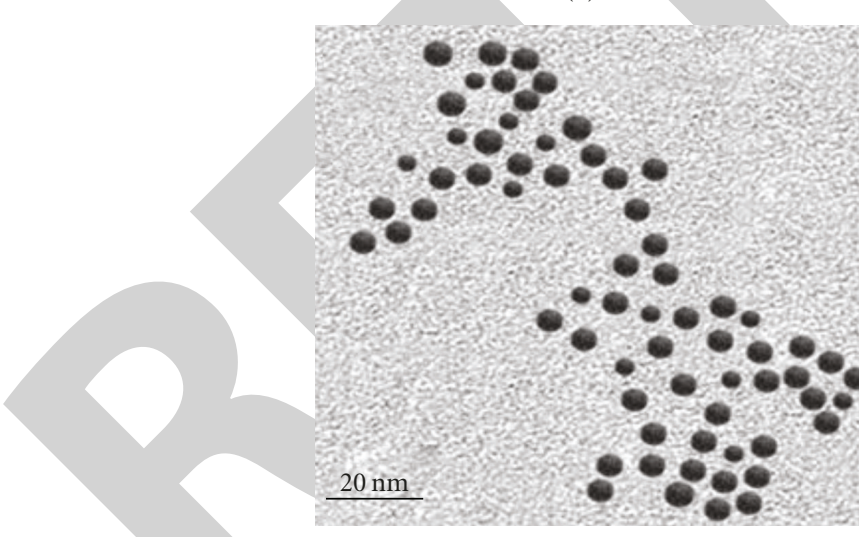

(c)

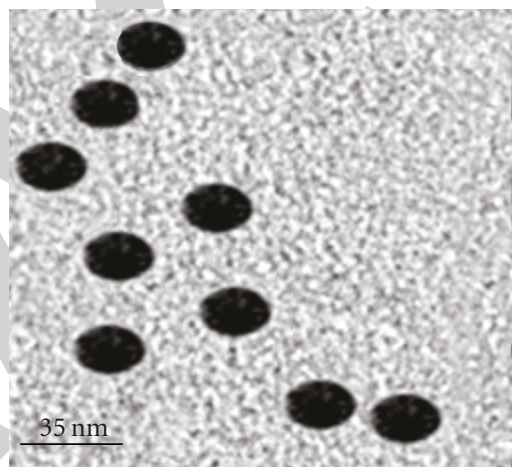

(b)

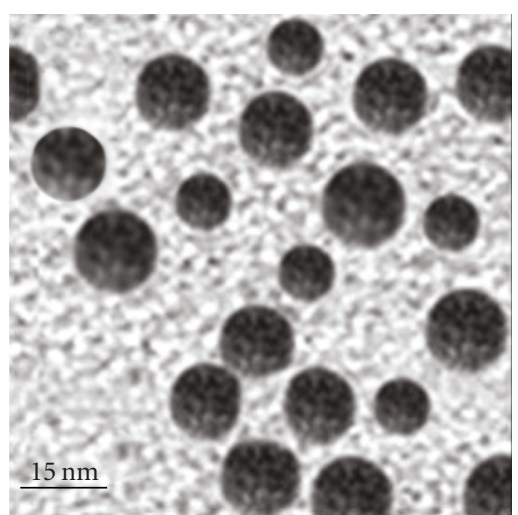

(d)

FIgURE 3: HRTEM image of the biosynthesized silver nanoparticles showing various particle sizes at (a and c) $25^{\circ} \mathrm{C},(\mathrm{b}$ and $\mathrm{d}) 60^{\circ} \mathrm{C}$.

nanoparticles is reduced. In the $10^{-3} \mathrm{M}$, the size of the synthesized nanoparticle is $50 \mathrm{~nm}$ and $35 \mathrm{~nm}$ at $25^{\circ} \mathrm{C}$ and $60^{\circ} \mathrm{C}$, respectively. Similarly, in the case of $10^{-4} \mathrm{M}$, the size of the synthesized nanoparticle is $20 \mathrm{~nm}$ and $15 \mathrm{~nm}$ at $25^{\circ} \mathrm{C}$ and $60^{\circ} \mathrm{C}$, respectively.

The biologically synthesized silver nanoparticles exhibited excellent antibacterial activity against the bacterial pathogens Staphylococcus aureus (Gram positive), Escherichia coli, and Pseudomonas aeruginosa (Gram negative) [31]. It has been reported that antibacterial effect was size and dose dependant and was more pronounced against Gram-negative bacteria than Gram-positive bacteria. But the present study clearly indicates that the synthesized silver nanoparticles have good antibacterial action against Gram-positive organism than Gram-negative organisms (Figure 4 and Table 1). The antimicrobial activities of colloidal silver particles are 

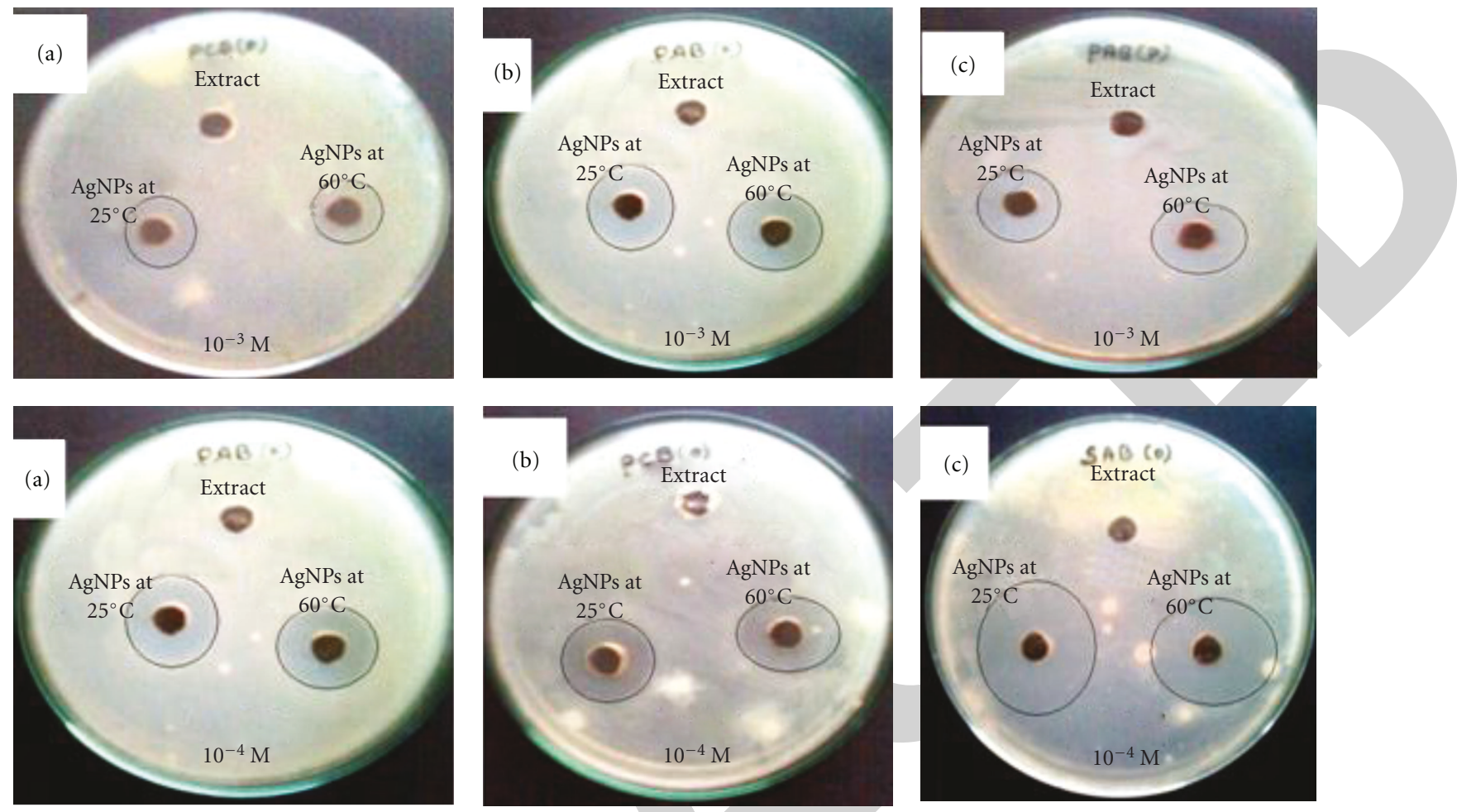

Figure 4: Zone of inhibition of silver nanoparticles against (a) Escherichia coli, (b) Pseudomonas aeruginosa, and (c) Staphylococcus aureus.

TABLE 1: Zone of inhibition ( $\mathrm{mm}$ ) of biologically synthesized silver nanoparticles against bacterial pathogens.

\begin{tabular}{|c|c|c|c|c|c|}
\hline \multirow[t]{2}{*}{ S. NO } & \multirow[t]{2}{*}{ Test organism } & \multicolumn{2}{|c|}{$\begin{array}{l}10^{-3} \mathrm{M} \text { AgNPs } \\
\text { synthesized at }\end{array}$} & \multicolumn{2}{|c|}{$\begin{array}{l}10^{-4} \mathrm{M} \text { AgNPs } \\
\text { synthesized at }\end{array}$} \\
\hline & & $25^{\circ} \mathrm{C}$ & $60^{\circ} \mathrm{C}$ & $25^{\circ} \mathrm{C}$ & $60^{\circ} \mathrm{C}$ \\
\hline (1) & Escherichia coli & 7.3 & 7.7 & 7.3 & 8 \\
\hline (2) & $\begin{array}{c}\text { Pseudomonas } \\
\text { aeruginosa }\end{array}$ & 8.3 & 9 & 8.8 & 9.5 \\
\hline (3) & $\begin{array}{c}\text { Staphylococcus } \\
\text { aureus }\end{array}$ & 14 & & 14.6 & 16.4 \\
\hline
\end{tabular}

\begin{tabular}{lll} 
aureus & 16.4 \\
\hline
\end{tabular}

influenced by the dimensions of the particles. The smaller particles lead to the greater antimicrobial effects [32]. The effect of antibacterial activity is higher in the case of silver nanoparticles synthesized at $60^{\circ} \mathrm{C}$ compared to $25^{\circ} \mathrm{C}$ because of being smaller in size $[31,33]$.

It is necessary to emphasize that the tested silver nanoparticles have bactericidal effects resulting not only in inhibition of bacterial growth but also in killing bacteria. Experiments conducted using the scanning tunneling electron microscopy (STEM) and X-ray energy dispersive spectrometer (EDS) showed that silver nanoparticles not only at the surface of cell membrane, but also inside the bacteria [34]. This suggests the possibility that the silver nanoparticles may also penetrate inside the bacteria and cause damage by interacting with phosphorus and sulfur containing compounds such as DNA [35]. The exact of inhibition of bacterial growth reported in this study is dependent on the concentration and number of nanoparticles in medium.

\section{Conclusions}

Silver nanoparticles were synthesized by Polyalthia longifolia leaves extract along with D-sorbitol. The spectroscopic characterization from UV-visible, FTIR, and TEM supports the stability of the biosynthesized nanoparticles. The nanosilver was found to have wider antimicrobial activity in Gram positive than Gram negative organisms. We believe that the silver nanoparticle has great potential for applications in catalysis, biomedical, and pharmaceutical industries.

\section{References}

[1] H. Jiang, S. Manolache, A. C. L. Wong, and F. S. Denes, "Plasma-enhanced deposition of silver nanoparticles onto polymer and metal surfaces for the generation of antimicrobial characteristics," Journal of Applied Polymer Science, vol. 93, no. 3, pp. 1411-1422, 2004.

[2] D. V. Parikh, T. Fink, K. Rajasekharan et al., "Antimicrobial silver/sodium carboxymethyl cotton dressings for burn wounds," Textile Research Journal, vol. 75, no. 2, pp. 134-138, 2005.

[3] V. Alt, T. Bechert, P. Steinrücke et al., "An in vitro assessment of the antibacterial properties and cytotoxicity of nanoparticulate silver bone cement," Biomaterials, vol. 25, no. 18, pp. 4383-4391, 2004.

[4] G. Gosheger, J. Hardes, H. Ahrens et al., "Silver-coated megaendoprostheses in a rabbit model-an analysis of the 
infection rate and toxicological side effects," Biomaterials, vol. 25, no. 24, pp. 5547-5556, 2004.

[5] M. E. Rupp, T. Fitzgerald, N. Marion et al., "Effect of silver-coated urinary catheters: efficacy, cost-effectiveness, and antimicrobial resistance," American Journal of Infection Control, vol. 32, no. 8, pp. 445-450, 2004.

[6] S. Ohashi, S. Saku, and K. Yamamoto, "Antibacterial activity of silver inorganic agent YDA filler," Journal of Oral Rehabilitation, vol. 31, no. 4, pp. 364-367, 2004.

[7] M. Bosetti, A. Masse, E. Tobin, and M. Cannas, "Silver coated materials for external fixation devices: in vitro biocompatibility and genotoxicity," Biomaterials, vol. 23, no. 3, pp. 887-892, 2002.

[8] H. J. Lee and S. H. Jeong, "Bacteriostasis and skin innoxiousness of nanosize silver colloids on textile fabrics," Textile Research Journal, vol. 75, no. 7, pp. 551-556, 2005.

[9] R. W. Y. Sun, R. Chen, N. P. Y. Chung, C. M. Ho, C. L. S. Lin, and C. M. Che, "Silver nanoparticles fabricated in hepes buffer exhibit cytoprotective activities toward HIV-1 infected cells," Chemical Communications, no. 40, pp. 5059-5061, 2005.

[10] M. Gutierrez and A. Henglein, "Formation of colloidal silver by "push-pull" reduction of $\mathrm{Ag}^{+}$," Journal of Physical Chemistry, vol. 97, no. 44, pp. 11368-11370, 1993.

[11] T. Klaus, R. Joerger, E. Olsson, and C. G. Granqvist, "Silverbased crystalline nanoparticles, microbially fabricated," Proceedings of the National Academy of Sciences of the United States of America, vol. 96, no. 24, pp. 13611-13614, 1999.

[12] Y. Konishi, K. Ohno, N. Saitoh et al., "Bioreductive deposition of platinum nanoparticles on the bacterium Shewanella algae," Journal of Biotechnology, vol. 128, no. 3, pp. 648-653, 2007.

[13] B. Nair and T. Pradeep, "Coalescence of nanoclusters and formation of submicron crystallites assisted by Lactobacillus," Crystal Growth and Design, vol. 2, no. 4, pp. 293-298, 2002.

[14] I. Willner, R. Baron, and B. Willner, "Growing metal nanoparticles by enzymes," Advanced Materials, vol. 18, no. 9, pp. 1109-1120, 2006.

[15] S. S. Shankar, A. Rai, B. Ankamwar, A. Singh, A. Ahmad, and M. Sastry, "Biological synthesis of triangular gold nanoprisms," Nature Materials, vol. 3, no. 7, pp. 482-488, 2004.

[16] D. Philip, C. Unni, S. Aromal, and V. K. Vidhu, "Murraya Koenigii leaf-assisted rapid green synthesis of silver and gold nanoparticles," Spectrochimica Acta Part A, vol. 78, no. 2, pp. 899-904, 2011.

[17] R. Veerasamy, T. Z. Xin, S. Gunasagaran et al., "Biosynthesis of silver nanoparticles using mangosteen leaf extract and evaluation of their antimicrobial activities," Journal of Saudi Chemical Society, vol. 15, no. 2, pp. 113-120, 2011.

[18] D. Philip, "Mangifera Indica leaf-assisted biosynthesis of welldispersed silver nanoparticles," Spectrochimica Acta Part A, vol. 78, no. 1, pp. 327-331, 2011.

[19] S. P. Dubey, M. Lahtinen, and M. Sillanpaa, "Tansy fruit mediated greener synthesis of silver and gold nanoparticles," Process Biochemistry, vol. 45, no. 7, pp. 1065-1071, 2010.

[20] S. L. Smitha, D. Philip, and K. G. Gopchandran, "Green synthesis of gold nanoparticles using Cinnamomum zeylanicum leaf broth," Spectrochimica Acta Part A, vol. 74, no. 3, pp. 735739, 2009.

[21] A. R. V. Nestor, V. S. Mendieta, M. A. C. Lopez, R. M. G. Espinosa, M. A. C. Lopez, and J. A. A. Alatorre, "Solventless synthesis and optical properties of $\mathrm{Au}$ and Ag nanoparticles using Camellia sinensis ," Materials Letters, vol. 62, no. 17-18, pp. 3103-3105, 2008.
[22] S. S. Shankar, A. Rai, A. Ahmad, and M. Sastry, "Rapid synthesis of $\mathrm{Au}, \mathrm{Ag}$, and bimetallic $\mathrm{Au}$ core-Ag shell nanoparticles using neem (Azadirachta indica) leaf broth," Journal of Colloid and Interface Science, vol. 275, no. 2, pp. 496-502, 2004.

[23] C. Y. Chen, F. R. Chang, Y. C. Shih et al., "Cytotoxic constituents of Polyalthia longifolia var. pendula," Journal of Natural Products, vol. 63, no. 11, pp. 1475-1478, 2000.

[24] A. Rai, A. Singh, A. Ahmad, and M. Sastry, "Role of halide ions and temperature on the morphology of biologically synthesized gold nanotriangles," Langmuir, vol. 22, no. 2, pp. 736-741, 2006.

[25] B. J. Wiley, S. H. Im, Z. Y. Li, J. McLellan, A. Siekkinen, and Y. Xia, "Maneuvering the surface plasmon resonance of silver nanostructures through shape-controlled synthesis," Journal of Physical Chemistry B, vol. 110, no. 32, pp. 15666-15675, 2006.

[26] J. Y. Song and B. S. Kim, "Rapid biological synthesis of silver nanoparticles using plant leaf extracts," Bioprocess and Biosystems Engineering, vol. 32, no. 1, pp. 79-84, 2009.

[27] A. M. Fayaz, K. Balaji, P. T. Kalaichelvan, and R. Venkatesan, "Fungal based synthesis of silver nanoparticles-an effect of temperature on the size of particles," Colloids and Surfaces B, vol. 74, no. 1, pp. 123-126, 2009.

[28] H. Bar, D. K. Bhui, G. P. Sahoo, P. Sarkar, S. P. De, and A. Misra, "Green synthesis of silver nanoparticles using latex of Jatropha curcas," Colloids and Surfaces A, vol. 339, no. 1-3, pp. 134-139, 2009.

[29] K. B. Narayanan and N. Sakthivel, "Coriander leaf mediated biosynthesis of gold nanoparticles," Materials Letters, vol. 62, no. 30, pp. 4588-4590, 2008.

[30] A. Gole, C. Dash, V. Ramakrishnan et al., "Pepsin-gold colloid conjugates: preparation, characterization, and enzymatic activity," Langmuir, vol. 17, no. 5, pp. 1674-1679, 2001.

[31] M. Singh, S. Singh, S. Prasad, and I. S. Gambhir, "Nanotechnology in medicine and antibacterial effect of silver nanoparticles," Digest Journal of Nanomaterials and Biostructures, vol. 3, no. 3, pp. 115-122, 2007.

[32] C. Baker, A. Pradhan, L. Pakstis, J. Pochan Darrin, and S. S. Ismat, "Synthesis and antibacterial properties of silver nanoparticles," Journal of Nanoscience and Nanotechnology, vol. 5, no. 2, pp. 244-249, 2005.

[33] C. Carlson, S. M. Hussein, A. M. Schrand et al., "Unique cellular interaction of silver nanoparticles: size-dependent generation of reactive oxygen species," Journal of Physical Chemistry B, vol. 112, no. 43, pp. 13608-13619, 2008.

[34] J. R. Morones, J. L. Elechiguerra, A. Camacho et al., "The bactericidal effect of silver nanoparticles," Nanotechnology, vol. 16, no. 10, pp. 2346-2353, 2005.

[35] D. W. Hatchett and H. S. White, "Electrochemistry of sulfur adlayers on the low-index faces of silver," Journal of Physical Chemistry, vol. 100, no. 23, pp. 9854-9859, 1996. 